\title{
Genome
}

\section{Challenges for assessing vertebrate diversity in turbid Saharan water-bodies using environmental DNA}

\begin{tabular}{|c|c|}
\hline Journal: & Genome \\
\hline Manuscript ID & gen-2018-0071.R2 \\
\hline Manuscript Type: & Note \\
\hline $\begin{array}{r}\text { Date Submitted by the } \\
\text { Author: }\end{array}$ & 13-Sep-2018 \\
\hline Complete List of Authors: & $\begin{array}{l}\text { Egeter, Bastian; Universidade do Porto Centro de Investigacao em } \\
\text { Biodiversidade e Recursos Geneticos, } \\
\text { Peixoto, Sara; Universidade do Porto Centro de Investigacao em } \\
\text { Biodiversidade e Recursos Geneticos; Universidade do Porto, } \\
\text { Departamento de Biologia da Faculdade de Ciências } \\
\text { Brito, José Carlos; Universidade do Porto Centro de Investigacao em } \\
\text { Biodiversidade e Recursos Geneticos; Universidade do Porto, } \\
\text { Departamento de Biologia da Faculdade de Ciências } \\
\text { Jarman, Simon; Curtin University, Molecular and Life Sciences ; CSIRO } \\
\text { National Collections and Marine Infrastructure, Environomics Future } \\
\text { Science Platform } \\
\text { Puppo, Pamela; Universidade do Porto Centro de Investigacao em } \\
\text { Biodiversidade e Recursos Geneticos } \\
\text { Velo-Antón, Guillermo; Universidade do Porto Centro de Investigacao em } \\
\text { Biodiversidade e Recursos Geneticos }\end{array}$ \\
\hline Keyword: & eDNA, spike, Mauritania, vertebrate, turbid \\
\hline $\begin{array}{r}\text { Is the invited manuscript for } \\
\text { consideration in a Special } \\
\text { Issue? : }\end{array}$ & 7th International Barcode of Life \\
\hline
\end{tabular}

\section{SCHOLARONE" Manuscripts}


1 Challenges for assessing vertebrate diversity in turbid Saharan water-bodies using environmental 2 DNA

4 Bastian Egeter ${ }^{1 *}$, Sara Peixoto ${ }^{1,2}$, José C. Brito ${ }^{1,2}$, Simon Jarman ${ }^{3,4}$, Pamela Puppo ${ }^{1}$, Guillermo 5 Velo-Antón ${ }^{1}$

6

$7 \quad{ }^{1}$ CIBIO/InBIO, Centro de Investigação em Biodiversidade e Recursos Genéticos da

8 Universidade do Porto, Instituto de Ciências Agrárias de Vairão, R. Padre Armando Quintas 7, 9 4485-661, Vairão, Portugal.

$10{ }^{2}$ Departamento de Biologia da Faculdade de Ciências, Universidade do Porto, Rua Campo 11 Alegre, 4169-007 Porto, Portugal

$12{ }^{3}$ Trace and Environmental DNA (TrEnD) laboratory, Molecular and Life Sciences, Curtin 13 University, WA, 6102, Australia

$14{ }^{4}$ Environomics Future Science Platform, CSIRO National Collections and Marine Infrastructure, 15 Crawley, W.A., 6009, Australia

$17 *$ Corresponding author: Bastian Egeter

$18 \mathrm{CIBIO} / \mathrm{InBIO}$, Centro de Investigação em Biodiversidade e Recursos Genéticos da Universidade 19 do Porto, Instituto de Ciências Agrárias de Vairão, R. Padre Armando Quintas 7, 4485-661, 20 Vairão, Portugal.

21 Tel: +351252660411

22 Email: bastianegeter@yahoo.ie 


\section{ABSTRACT}

25 The Sahara desert is the largest warm desert in the world and a poorly explored area. Small

26 water-bodies occur across the desert and are crucial habitats for vertebrate biodiversity.

27 Environmental DNA (eDNA) is a powerful tool for species detection and is being increasingly

28 used to conduct biodiversity assessments. However, there are a number of difficulties with

29 sampling eDNA from such turbid water-bodies and it is often not feasible to rely on electrical

30 tools in remote desert environments. We trialled a manually-powered filtering method in

31 Mauritania, using pre-filtration to circumvent problems posed by turbid water in remote arid

32 areas. From nine vertebrate species expected in the water-bodies, four were detected visually,

33 two via metabarcoding and one via both methods. Difficulties filtering turbid water led to severe

34 constraints, limiting the sampling protocol to only one sampling point per study site, which alone

35 may largely explain why many of the expected vertebrate species were not detected. The

36 amplification of human DNA using general vertebrate primers is also likely to have contributed

37 to the low number of taxa identified. Here we highlight a number of challenges that need to be

38 overcome to successfully conduct metabarcoding eDNA studies for vertebrates in desert

39 environments in Africa.

44 Keywords: eDNA, spike, Mauritania, vertebrate, turbid, desert, biodiversity 
https://mc06.manuscriptcentral.com/genome-pubs 
47 Knowledge on species distribution is essential in many fields of biology, and the identification of areas with high species richness is crucial to protect global and regional hotspots of biodiversity (Pimm et al. 2014). Information about biodiversity distribution is still scarce in remote and unexplored areas, such as deserts and arid regions (Brito et al. 2014). The Sahara desert is the largest warm desert in the world and a poorly explored area due to the remoteness, size and longterm political instability of the region (Brito et al. 2014). Small and fragile water-bodies surrounded by sandy areas, such as mountain rock pools (gueltas) and floodplains, occur across the Sahara desert acting as local biodiversity hotspots (Vale et al. 2015). For example, Mauritanian mountain rock pools harbour a disproportionately high representation of desert biodiversity (32\% of the analysed vertebrates and $78 \%$ of the country's endemics; see Vale et al. 2015). Local human activities are also dependent on water-bodies, thus, the long-term conservation of these fragile and unique ecosystems requires a better assessment of local biodiversity levels and potential human-related conflicts.

Environmental DNA (eDNA) is a powerful and cost-effective tool for species detection and is

61 being increasingly used to conduct biodiversity assessments (Jerde et al. 2011; Thomsen et al.

62 2012). Most studies using eDNA "metabarcoding" for detecting vertebrates from water-bodies

63 concentrate eDNA prior to DNA extraction by filtering (e.g. Lopes et al. 2017; Robson et al.

64 2016). Filtering generally results in higher amounts of eDNA being extracted than precipitating

65 directly from water, since much higher volumes of water are processed when filtering (Adrian-

66 Kalchhauser and Burkhardt-Holm 2016; Eichmiller et al. 2016; Hinlo et al. 2017). However,

67 previous studies have so far focused on temperate and tropical environments, and the efficacy of

68 eDNA monitoring in water-bodies in extreme arid environments, such as desert water-bodies, 
69 remains unknown. In particular, it was known from previous studies that the water in gueltas is

70 often highly turbid (Verheye and Dumont 1984), which can lead to limitations in filtering any

71 substantial volumes of water (Robson et al. 2016; Spens et al. 2017; Turner et al. 2014). One

72 method to counter these limitations is pre-filtering of water samples through membranes with a

73 larger pore size (see Majaneva et al. 2018). Another considerable difficulty with conducting

74 research in remote desert environments is that it is often not feasible to rely on electrical tools.

75 For the present study, we aimed to trial a manually-powered filtering method for collecting 76 eDNA samples for metabarcoding, using pre-filtration to circumvent the problems posed by

77 highly turbid water in remote arid areas. To validate the protocol we included a DNA spike: a

78 known quantity of DNA from a pre-selected source (i.e. from species not present in the study

79 area) added to environmental water samples prior to filtering.

80

81

82

\section{MATERIALS AND METHODS}

\section{Field sampling}

The study was conducted in Mauritania (latitude from N14.4 to N27.2 and longitude from W4.5 to W17.1) during an overland expedition in April 2017, coinciding with the dry season peak. This region has four mountain chains (Adrar Atar, Tagant, Assaba and Afollé) and is located in the transition between Sahara and Sahel ecoregions. Three permanent water-bodies were surveyed: Atar dam (N20.532 W13.044; c. 20,000 m²) and Hamdoûn rock pool (N20.323 W13.142; c. 5,000 $\mathrm{m}^{2}$ ) in the Adrar Atar mountains, and Matmâta river-bed (N17.887 W12.111; c. $10,000 \mathrm{~m}^{2}$ ) in the Tagant mountains (Figure 1). These water-bodies are characterised by high levels of water turbidity partially due to the faecal contamination by domestic animals and herdsmen exploitation (see Vale et al. 2015). They had previously been inspected during diurnal 
91 and nocturnal surveys between 2007 and 2013 using several distinct methodologies (e.g. dip

92 nets, live traps and camera traps) as well as indirect observations (e.g. faeces, footprints, tracks or burrows) to catalogue the vertebrates occurring there (Vale et al. 2015). During the current study, visual encounter surveys along the margins of the water-bodies were made by at least two persons to detect the presence of amphibians, fishes, mammals and reptiles.

Each water-body was then sampled at one sampling point. The original study design included multiple sampling points, but fieldwork was severely limited as a consequence of the difficulties encountered with filtering, namely that up to two hours were required to filter each water sample. At each sampling point $5 \mathrm{~L}$ water was collected in a container. The entire volume was first prefiltered through a $1 \mu \mathrm{m}$ polypropylene filter (Airwatertech, Belgium) housed in a Cintropur NW18 filtering capsule (Airwatertech, Belgium). This pore size was chosen based on our observations that pre-filtering water from Mauritanian gueltas through $20 \mu \mathrm{m}, 10 \mu \mathrm{m}$ and $5 \mu \mathrm{m}$ pre-filters did not substantially reduce the suspended sediment in the filtrate, which resulted in rapid clogging during the final filtering step. Thus, a smaller pore size was necessary. A dual action hand-powered vacuum pump (Tribord, France) was used to draw the water through the filtration system. The filtrate from this first step was captured and $500 \mathrm{~mL}$ was transferred to a Nalgene $500 \mathrm{~mL}$ filter holder (ThermoFisher Scientific, USA) fitted with a $47 \mathrm{~mm}$ diameter 0.45 $\mu \mathrm{m}$ nitrocellulose Whatman filter (GE Healthcare, USA). At Atar and Hamdoûn, even after the pre-filtering step, it was necessary to use between two and four final filters to pass through the desired $500 \mathrm{~mL}$ water, due to filters clogging. Both the pre-filter and final filters were kept and stored separately in a $50 \mathrm{~mL}$ and a $2 \mathrm{~mL}$ tube respectively, which were topped up with $96 \%$ ethanol. At each water-body, a negative control was also included, which consisted of filtering 2 $\mathrm{L} \mathrm{dH}_{2} \mathrm{O}$ through a sterile $0.45 \mu \mathrm{m}$ filter. Disposable gloves were used for handling filters and 
114 were changed between sampling points. All equipment was washed, soaked in $20 \%$ bleach

115 overnight and thoroughly rinsed between sampling sites.

116 There was high turbidity in all water-bodies and at Hamdoûn it was only possible to filter $4 \mathrm{~L}$

117 through the pre-filter, before it clogged, even though these have a relatively high surface area of

118 c. $260 \mathrm{~cm}^{2}$, compared to the commonly used $47 \mathrm{~mm}$ diameter disc filters, which have a surface

119 area of c. $17 \mathrm{~cm}^{2}$.

120 In order to validate the filtering method, the entire procedure at each sampling point was

121 repeated with the addition of a pre-prepared DNA positive control fragment. To prepare this

122 "spike" of control DNA, the concentration of tissue-extracted DNA from five different

123 amphibian species occurring in northern Maghreb, but known to be absent from Mauritania, was

124 measured using the Qubit HS DNA Assay (ThermoFisher Scientific, USA). Separate $1.5 \mathrm{~mL}$

125 tubes were prepared, each containing desiccated DNA in the following amounts: Discoglossus

126 pictus (50 ng), Sclerophrys mauritanicus (25 ng), Discoglossus scovazzi (1.25 ng) and

127 Pelophylax saharicus (0.25 ng). At each site, before the pre-filtering step, this desiccated DNA

128 was rehydrated in $1 \mathrm{~mL} \mathrm{dH_{2 }} \mathrm{O}$ and added to the $5 \mathrm{~L}$ container, which was subsequently shaken

129 thoroughly. This resulted in concentrations of DNA in the 5 L container of 10, 5, 0.25 and 0.05

$130 \mathrm{ng} / \mathrm{L}$ for each species respectively. To assess whether the DNA in the spikes had become

131 degraded between preparation in the laboratory and rehydration in the field, two spikes were

132 rehydrated in the field and filtered through separate $0.45 \mu \mathrm{m}$ filters, which were stored in the

133 same manner as for other filters. At Matmâta, again due to the amount of time it took to filter

134 water samples, only one $5 \mathrm{~L}$ water sample was sampled, which included the spike DNA.

\section{DNA extraction}


DNA extractions were carried out in a positive-pressure lab (CIBIO-InBIO, Vairão Campus,

137 Portugal), following strict protocols including disposable lab wear, UV sterilization of all equipment before entering the lab, and cleaning lab surfaces with bleach between extraction batches. Only environmental and faecal samples are permitted to enter this lab. Other biological tissues, already-extracted DNA and PCR products are forbidden. Handling and cutting of all

141 filters was done using flame-sterilized scissors and forceps, on disposable dissection trays. The 142 larger pre-filters were quartered. Adapting the protocol used by Valentini et al. (2016), two of the 143 quarters were placed in separate $50 \mathrm{~mL}$ tubes with $30 \mathrm{~mL}$ resuspension buffer each $(50 \mathrm{mM}$ Tris, 144 10mM EDTA), and shaken thoroughly for $5 \mathrm{~min}$ at $20 \mathrm{~Hz}$ (Retsch $400 \mathrm{MM}$; Retsch, Germany). 145 The buffer from both tubes was then combined and filtered through a $0.45 \mu \mathrm{m}$ filter. From here, 146 the extractions for all $0.45 \mu \mathrm{m}$ filters was identical. Each filter was cut in half, placed in a $5 \mathrm{~mL}$ 147 tube and excess ethanol was evaporated at room temperature. To each tube, $2 \mathrm{~mL}$ lysis buffer 148 (0.1 M Tris-HCl, 0.1 M EDTA, 0.01 M NaCl, $1 \%$ N-lauroyl sarcosine, pH 7.5-8; Maudet et al. 149 2004), was added and kept at $54{ }^{\circ} \mathrm{C}$ for $0.5 \mathrm{~h}$. From here the EZNA Tissue DNA kit was used 150 following the manufacturer's instructions, using $300 \mu \mathrm{L} \mathrm{BL}$ Buffer, $300 \mu \mathrm{L}$ ethanol and eluting 151 in $50 \mu \mathrm{L}$ Elution Buffer.

\section{PCR and sequencing}

153 We used a primer designed to target all vertebrates - here referred to as 12SV5.1, as the original 154 publication did not specifically name the pair (Riaz et al. 2011). The 12SV5.1 primer pair 155 includes 12SV5.1_F ACTGGGATTAGATACCCC and 12SV5.1_R

156 TAGAACAGGCTCCTCTAG that targets a c. 105 bp region of the mitochondrial $12 \mathrm{~S}$ rRNA 157 gene. PCR conditions were: $10 \mu \mathrm{L}$ reactions containing $2 \mu \mathrm{L}$ DNA, $5 \mu \mathrm{L}$ Multiplex PCR Master 158 Mix (Qiagen, USA) and $0.3 \mu \mathrm{M}$ of each primer. The thermal cycling profile was an initial step of 
159

160

161

162

163

164

165

166

167

168

169

170

171

172

173

174

175

176

177

178

179

180

$95^{\circ} \mathrm{C}$ for $10 \mathrm{~min}$; then 35 cycles of $95^{\circ} \mathrm{C}$ for $30 \mathrm{~s}, 51^{\circ} \mathrm{C}$ for $30 \mathrm{~s}$, and $72{ }^{\circ} \mathrm{C}$ for $30 \mathrm{~s}$; with a final extension of $72^{\circ} \mathrm{C}$ for $10 \mathrm{~min}$. Amplification success was confirmed by electrophoresis in $2 \%$ agarose gels stained with GelRed (Biotium, USA). To prepare samples for high-throughout sequencing, a second PCR was conducted using $10 \mu \mathrm{L}$ reactions containing: $1 \mu \mathrm{M}$ of each indexprimer combination (Gansauge and Meyer 2013; Kircher et al. 2011), $5 \mu \mathrm{L} 2 \mathrm{X}$ KAPA HiFi HotStart ReadyMix (Kapa Biosystems), and $2 \mu \mathrm{L}$ of previous PCR product diluted 1:10 using $10 \mathrm{mM}$ Tris. The thermal cycling profile consisted of an initial step of $95^{\circ} \mathrm{C}$ for $3 \mathrm{~min} ; 10$ cycles of: $95^{\circ} \mathrm{C}$ for $30 \mathrm{~s}, 55^{\circ} \mathrm{C}$ for $30 \mathrm{~s}$, and $72^{\circ} \mathrm{C}$ for $30 \mathrm{~s}$; and a final extension of $72^{\circ} \mathrm{C}$ for $5 \mathrm{~min}$. The resulting PCR product was cleaned using 1.2 X by volume AMPure XP beads (Beckman Coulter) following the manufacturer's instructions with the exception that $80 \%$ ethanol was used instead of $70 \%$. Elution was done in $25 \mu \mathrm{L}$ Tris $10 \mathrm{mM}$. Library quality was assessed by measuring DNA concentration of each cleaned PCR product using Nanodrop 2000 (Thermo Fisher Scientific) and each PCR product was normalized to $15 \mathrm{nM}$ using $10 \mathrm{mM}$ Tris $\mathrm{pH} 8.50 .1 \%$ Tween. The final pool was obtained by combining $5 \mu \mathrm{L}$ from each normalised sample. The quality of the final pool was assessed by qPCR using KAPA Illumina Library Quantification (Illumina) following the manufacturer's instructions. Illumina paired-end sequencing was performed using a 300-cycle Illumina MiSeq Micro V2 Kit (Illumina) on an Illumina MiSeq sequencer housed at CIBIO-InBio (Vairão Campus, Portugal). The run was shared between projects, so that the pool for the present study represented $15 \%$ of the final loaded pool.

\section{Sequence data}

Reads produced on the Miseq were demultiplexed using BASESPACE

(basespace.illumina.com). The Obitools package (v1.2.11; Boyer et al. 2016) was used for the 
181 following: paired-end reads were aligned, alignments with a score $<50$ were removed, reads

182 without both primer sequences were removed, reads within each sample were clustered only if

$183100 \%$ identical, primer sequences were trimmed, reads $<75 \mathrm{bp}$ and $>120 \mathrm{bp}$ were removed, as

184 were singletons. The resulting sequences were BLASTed against the NCBI Nucleotide database

185 using the MEGABLAST algorithm (Zhang et al. 2000). BLAST results were assigned to taxa

186 using MEGAN (Community Edition 6.10.8; Huson et al. 2016) with the default parameters apart

187 from the following: $\operatorname{minScore}=150.0$, minPercentIdentity=97.0, topPercent $=10.0$,

188 minSupportPercent $=0.0$. One taxon, Sus scrofa, was observed in a number of samples, but with a 189 relatively low number of reads (maximum contribution to any sample was $0.9 \%$ ). As one of the 190 other pools in the MiSeq run consisted of a high number of wild pig (S. scrofa) reads, these reads 191 were considered to be the result of tag jumping. Consequently, all taxa with a read count less 192 than $1 \%$ of the sample read count were removed. Eight other taxa (including hominids) were 193 excluded from the entire dataset based on relatively high read counts in either field, extraction or 194 PCR negatives, or in one case because the genus (Podarcis) is not known from Mauritania.

\section{RESULTS}

196 At the time of sampling, adults of the crowned frog (Hoplobatrachus occipitalis) and of the eel 197 catfish (Clarias sp.), were detected at all sites via visual surveys (Table 1). The west African 198 crocodile (Crocodylus suchus) and the Nile monitor (Varanus niloticus) were observed in the 199 water at Matmâta (Table 1). No other vertebrates were observed.

200 Cluster density for the run was $762,000 / \mathrm{mm}^{2}$ and the Clusters Passing Filter was $88 \%$. Prior to 201 bioinformatic filtering almost 350,000 reads were obtained across a total 40 PCR products (Table 202 S1). After filtering, before removing hominid-assigned reads and other potential contaminants, 
203

204

205

206

207

208

209

210

211

212

213

214

215

216

217

218

219

220

221

222

223

224

225

over 264,099 reads remained (average $=7,181$ reads / sample, excluding negative controls).

Following removal of human-assigned reads and other potential contaminants an average of 650

reads / sample was obtained. Hominid reads accounted for 184,675 of those filtered out, while

5,104 reads were attributed to taxa identified in negative controls (see Table S2). Using DNA

extracted from the final filters produced the majority of the reads and taxa detected (Table S3).

In only one case was a taxon identified at a site using DNA extracted from the pre-filter, but not the corresponding final filter.

Table 1 includes a list of taxa that have been observed in these water-bodies in previous studies

(Vale et al. 2015), as well as taxa that were detected visually or via metabarcoding (regardless of whether they were known from previous studies). Catfish DNA (assigned to Clarias) was detected at all sampling sites and one barbel species (Enteromius pobeguini), known to occur in the Atar region (Trape 2009), was identified at Hamdoûn (Table 1). The Clarias-assigned reads are most likely Clarias anguillaris, which is known to inhabit water-bodies in the Adrar Atar mountains and was identified during previous studies (Trape 2009; Verheye and Dumont 1984). A number of reads from Hamdoûn were also assigned to Enteromius eburneensis, but this species is not known from Mauritania (Vale et al. 2015). The E. eburneensis-assigned reads could be variants of E. pobeguini-assigned reads, however, as E. eburneensis-assigned reads did not match either species perfectly $(\leq 98 \%)$, it is also possible that these reads belong to a separate species, such as Enteromius macrops. Neither C. anguillaris nor E. macrops have representative $12 \mathrm{~S}$ sequences in the NCBI Nucleotide database, so this remains unconfirmed. Apart from one instance of Canis lupus and one instance of Podarcis, no other vertebrates were identified, even though a number of other vertebrate taxa were expected to be present based on previous surveys (Table 1). Reads assigned to C. lupus could be from domestic dog (Canis lupus 
226 familiaris) or possibly African golden wolf (Canis anthus) as the target fragment is identical for

227 these species.

228 The two positive control spike DNA samples, rehydrated and filtered in the field, resulted in

229 recovery and detection of the three species with higher DNA amounts, while the species with the

230 lowest amount of DNA in the spike was not detected (Figure 2). DNA spiked in to the initial $5 \mathrm{~L}$

231 water samples was only recovered from $0.45 \mu \mathrm{m}$ filters, despite being first passed through the 1

$232 \mu \mathrm{m}$ pre-filters. The recovery of DNA spiked in to water samples varied across sites: two of the

233 spike species were detected at Hamdoûn, one at Atar and none at Matmâta.

\section{DISCUSSION}

235 Frogs were observed at the time of sampling in all water-bodies and reptiles in the water at

236 Matmâta, but only two of the expected genera, both fish, were detected via eDNA. There were a

237 number of limitations to this study that may have led to the apparent paucity of results, including

238 small sample size (as a result of lengthy filtering methods and expedition time constraints), the

239 use of a single primer, amplification of human DNA in high proportions, observed contamination

240 and a lack of complete reference databases.

241 Spens et al. (2017) recognized that further research is needed to identify optimal filtering

242 procedures for highly productive and/or turbid waters. An important consideration in the present

243 study is that the pre-filtering step required up to two hours of manual pumping in order to

244 produce the vacuum necessary to draw water through the filter as it became more clogged. This

245 is a prohibitive amount of time for most study scenarios, particularly those in remote areas,

246 where expeditions are time-constrained. This constraint limited our sampling protocol to one

247 sampling point per site. This alone may largely explain why many of the expected vertebrate 
248 species were not detected, as multiple sampling points are required to maximize species detections (Goldberg et al. 2018). In any case, pre-filtering did not substantially aid the final filtering process as small particles remained in the filtrate and continued to cause clogging

251 problems for the final filters. This is despite the fact that our pre-filtering step used $1 \mu \mathrm{m}$ filters, 252 which is a smaller pore size than for other reported pre-filtering steps (e.g. Djurhuus et al. 2018;

253 Majaneva et al. 2018; Rees et al. 2014; Takahara et al. 2012). As we included eDNA captured 254 from pre-filters in our analyses, and detected only a single vertebrate taxon from just one pre255 filter sample, compared to detecting multiple vertebrate taxa from five (of the eight) final filter 256 samples (Table S3), it is evident that eDNA was, at least, not being entirely retained by the pre257 filter.

258 A number of studies have shown the benefits of using encapsulated filters, some with much 259 greater surface areas than the more commonly used disc filters, and although this has not yet 260 been explicitly tested for turbid water, these types of filtration units may provide an efficacious 261 alternative (Civade et al. 2016; Eva et al. 2016; Lopes et al. 2017; Spens et al. 2017; Valentini et 262 al. 2016; Vences et al. 2016). It may be that filtering, while efficacious in low-turbidity systems, 263 is not easily applied in such turbid systems and other, low-volume methods, such as 264 precipitation, bead extraction or centrifugation are the only solution (see Williams et al. 2017).

265 The primer pair chosen for the current study has been used in previous studies and the target 266 fragment has been applied successfully in assigning taxonomy for vertebrates in these and other 267 studies using closely-situated primer binding sites (Calvignac-Spencer et al. 2013; De Barba et 268 al. 2014; Kelly et al. 2014; Kocher et al. 2017a; Kocher et al. 2017b; Port et al. 2016; Riaz et al. 269 2011; Rodgers et al. 2017; Shehzad et al. 2012a; Shehzad et al. 2015; Shehzad et al. 2012b; 270 Xiong et al. 2016). Despite this, we did not detect some of the visually identified or expected 
271 taxa. It is also somewhat surprising that livestock species, which are known to frequent these

272 sites, were not detected via metabarcoding. A partial explanation is that the primers have a

273 number of mismatches to some of the taxa being targeted at these sites, especially the reptiles

274 (Table 1). However, this does not explain why visually detected species with zero primer

275 mismatches were not amplified. Future studies should consider the use of more than one primer

276 pair for vertebrate species detection, as has been often recommended for invertebrate studies

277 (e.g. Alberdi et al. 2018; Corse et al. 2017).

278 The amplification of human DNA is also very likely to have contributed to the low number of

279 taxa being identified in the present study, as $68 \%$ of the total reads obtained were assigned to

280 hominids. Amplification of human DNA is known to occur even using the most stringent

281 laboratory practices (Pääbo et al. 2004). Future studies should consider the use of human

282 blocking primers for this primer pair, similar to those used by Port et al. (2016).

283 Despite following strict protocols for extractions, a high number of hominid-assigned reads were 284 retrieved from all of our extraction controls, as well as some minor contamination from Felinae. 285 As these did not appear in our PCR negatives, this can be attributed to contamination during the 286 extraction step. This could be due to the use of shared laboratory reagents (namely the lysis

287 buffer) or incomplete flame sterilization of shared instruments. One PCR negative was

288 contaminated with Cercopithecinae, a group which is often studied in our institute. Finally, three 289 taxa (Gallus gallus, Hemidactylus agrius and Phyllopezus pollicaris) were identified from field 290 negatives. The source of this contamination remains unclear; it is possible the distilled water 291 used as a negative control became contaminated, or it may have occurred during downstream 292 extraction or PCR, in a non-systematic manner. 
293 Of the four taxa detected via metabarcoding, only one could be confidently assigned at the species level due to the lack of available reference databases, which presents a major issue for eDNA studies in Africa (Coey et al. 2015). It is likely that there are more COI than 12S barcodes currently available for African species, but difficulties designing primers for COI for vertebrate metabarcoding studies have been highlighted by a number of studies, as they tend to co-amplify DNA from many other taxonomic groups (Deagle et al. 2014; Kondo et al. 2016). Until more African species are barcoded and added to publically available databases, the only method to overcome this issue is to build local reference DNA databases based using target taxa expected to be present in the study area. Of course, this requires a considerable amount of additional effort to obtain tissue samples from many different species, as well as a priori knowledge of species expected at field sites.

One of the problems with eDNA studies is the unquantified variability between samples in species detection probability. Using DNA spikes can help to account for inter-site variability, act as quality control for extraction and PCR procedures and compare different workflow methodologies at every step from field capture to sequencing platform. Although DNA spikes have been widely applied during DNA extraction, preservation and PCR steps, the number of studies that have used DNA spikes during field sampling are very limited (see Furlan and Gleeson 2017). Walker et al. (2017) used extracted DNA as spikes to assess degradation of salamander DNA in soil prior to DNA extraction. Pochon et al (2013) used entire larvae as spikes to assess the detection limits of their assays. Green and Field (2012) spiked Escherichia coli cells into environmental water samples prior to filtering to assess the variability of DNA recovery among samples. In other studies, water collected from tanks or ponds containing known vertebrate species has been injected into study systems, primarily to investigate survival of 
eDNA in experimental systems (Barnes et al. 2014; Jerde et al. 2016; Shogren et al. 2016). It is

317 likely that the type of spike used will produce different recovery results. eDNA has a complex

318 physiochemical composition arising from the effects of biological, environmental and physical

319 conditions of a particular site. So it is difficult to discern what the ideal "eDNA spike" might comprise, with options ranging from any combination of whole individuals, cells, mitochondria,

321 whole extracted DNA, sheared DNA of different lengths or synthesized DNA. Furlan and

322 Gleeson (2017) recommend using endogenous eDNA to identify potential false negative results

323 under certain scenarios, but note that endogenous eDNA concentrations will vary, precluding

324 comparison of DNA capture methods.

325 In the current study, the species with the lowest amount of DNA in the spikes was not detected

326 from the positive controls, indicating that there may have been some degradation of spike DNA

327 during the expedition or the methods of recovery/detection were not sensitive enough for DNA at

328 this low level. As DNA from the other three species was detected, this was not a substantial

329 problem for the study. The fact that DNA was recovered from spikes added to the $5 \mathrm{~L}$ water

330 samples at concentrations as low as $5 \mathrm{ng} / \mathrm{L}$ provided evidence, for Atar and Hamdoûn, that the

331 field filtering process and downstream analyses were indeed adequate. The reasons for the

332 observed variation across sites in the detection of spiked DNA are unclear. It may be that the

333 concentrations used are at the lower limits of detection in general for the methods used in this

334 study, or it may be that other site-specific factors influenced the results, such as incomplete DNA

335 extraction due to partial clogging of extraction spin columns. We used the EZNA Tissue DNA

336 extraction kit as it has achieved good results in our laboratory previously and has been used in a

337 number of other eDNA studies (e.g. Pérez et al. 2013), although we are not aware of any studies

338 comparing the efficacy of this kit with other methods. More sampling is required to examine 
339 whether the individual water-body influences DNA recovery, but it is likely, as Liang and

340 Keeley (2013) found that $\mathrm{pH}$, ion concentration and suspended solid concentration all influenced

341 DNA recovery from spiked samples under laboratory conditions. Green and Field (2012) also

342 found that increased turbidity negatively affected amplification efficiency.

343 In the present study, spiked DNA was only recovered from $0.45 \mu \mathrm{m}$ filters, despite the water 344 being pre-filtered through a $1 \mu \mathrm{m}$ filter beforehand. It may be that $0.45 \mu \mathrm{m}$ is a more suitable 345 pore size for eDNA recovery, particularly for extracellular DNA and this might be especially 346 pertinent in environments with high concentrations of small-diameter suspended sediments (e.g. 347 clay), as these are known to adsorb DNA, but are $<1 \mu \mathrm{m}$. Alternatively, $1 \mu \mathrm{m}$ filters have often 348 been used to detect eDNA (Eichmiller et al. 2016; Turner et al. 2014), so it is also possible that 349 the extraction technique used in this study for the pre-filters was not as efficient as for the final 350 filters. Nitrocellulose filters have been used previously in many studies (reviewed by Rees et al. 351 2014) and resulted in the highest DNA yield in a comparison by Majaneva et al. (2018).

352 It is notable that species in the DNA spike were detected even at minute concentrations (at two 353 of three sites), although indigenous amphibian eDNA was not. A possible explanation for this is 354 that eDNA might be rapidly broken down in desert environments, as exposure to sunlight, UV 355 and higher temperatures is known to expedite the DNA degradation process (Pilliod et al. 2014;

356 Strickler et al. 2015). More research is needed to confirm this, but it may present another 357 challenge for conducting metabarcoding studies in remote desert environments.

358 In conclusion, several constraints originated during the present study, which contributed to the 359 very low number of taxa being identified via metabarcoding. First, high turbidity levels led to 360 clogging of filters during field sampling, and this was not alleviated by pre-filtering. This 
361 resulted in an increased amount of time being required per sample, which limited the study to

362 one sampling point per site. Additionally, the use of a single general vertebrate primer set

363 resulted in a high proportion of reads being assigned to hominids, which were likely the result of

364 human contamination during DNA extractions. Finally, a lack of complete reference databases

365 for Africa's vertebrates hindered the taxonomic assignment of sequences at species level. To

366 overcome these issues, we recommend the following: 1) alternative methods for capturing eDNA

367 (such as high-surface area encapsulated filters) should be tested in challenging desert

368 environments; 2) multiple primer sets should be used for vertebrate species detection; 3) human

369 blocking primers should be incorporated during amplification; and 4) local reference DNA

370 databases should be constructed. This study highlights the need for the development of better

371 eDNA techniques catered for challenging and remote desert environments, which are required if

372 eDNA studies are to be used for describing Africa's understudied vertebrate biodiversity.

\section{ACKNOWLEDGEMENTS}

374 This project has received funding from the European Union's Horizon 2020 research and 375 innovation programme under grant agreement No 668981. We thank F. Martínez-Freiría, F.

376 Sousa, J. Marques, F. Santarem, J.M. Pleguezuelos and M. Feriche for assistance during field

377 work. José C. Brito and Guillermo Velo-Antón are supported by Fundação para a Ciência e 378 Tecnologia (IF/00459/2013 and IF/ 01425/2014, respectively). We also thank three anonymous 379 reviewers for their contributions to improving this manuscript. 


\section{REFERENCES}

Adrian-Kalchhauser, I., and Burkhardt-Holm, P. 2016. An eDNA assay to monitor a globally invasive fish species from flowing freshwater. PloS One 11(1): e0147558. doi:10.1371/journal.pone.0147558.

Alberdi, A., Aizpurua, O., Gilbert, M.T.P., and Bohmann, K. 2018. Scrutinizing key steps for reliable metabarcoding of environmental samples. Methods Ecol. Evol. 9(1): 134-147. doi:10.1111/2041-210X.12849.

Barnes, M.A., Turner, C.R., Jerde, C.L., Renshaw, M.A., Chadderton, W.L., and Lodge, D.M. 2014. Environmental conditions influence eDNA persistence in aquatic systems. Environ. Sci. Technol. 48(3): 1819-1827. doi:10.1021/es404734p.

Boyer, F., Mercier, C., Bonin, A., Le Bras, Y., Taberlet, P., and Coissac, E. 2016. obitools: a unix-inspired software package for DNA metabarcoding. Mol. Ecol. Resour. 16(1): 176182. doi:10.1111/1755-0998.12428.

Brito, J.C., Godinho, R., Martínez-Freiría, F., Pleguezuelos, J.M., Rebelo, H., Santos, X., et al. 2014. Unravelling biodiversity, evolution and threats to conservation in the Sahara-Sahel. Biol. Rev. 89(1): 215-231. doi:10.1111/brv.12049.

Calvignac-Spencer, S., Merkel, K., Kutzner, N., Kühl, H., Boesch, C., Kappeler, P.M., et al. 2013. Carrion fly-derived DNA as a tool for comprehensive and cost-effective assessment of mammalian biodiversity. Mol. Ecol. 22(4): 915-924. 
400 401

402

403

404 405 406 407 408 409 410 411 412 413

414 415 416 417 418

Civade, R., Dejean, T., Valentini, A., Roset, N., Raymond, J.-C., Bonin, A., et al. 2016. Spatial representativeness of environmental DNA metabarcoding signal for fish biodiversity assessment in a natural freshwater system. PloS One 11(6): e0157366. doi:10.1371/journal.pone.0157366.

Coey, S., Fernández, C.A., Vogler, A.P., Yu, D., Atkinson, P., and Coates, A. Survey for African freshwater fish using DNA barcoding. In 35th Annual Conference of the International Association for Impact Assessment. Firenze Fiera Congress \& Exhibition Center, Florence, Italy, 20 - 23 April 20152015.

Corse, E., Meglécz, E., Archambaud, G., Ardisson, M., Martin, J.-F., Tougard, C., et al. 2017. A from-benchtop-to-desktop workflow for validating HTS data and for taxonomic identification in diet metabarcoding studies. Mol. Ecol. Resour. 17(6): e146-e159. doi:10.1111/1755-0998.12703.

De Barba, M., Miquel, C., Boyer, F., Mercier, C., Rioux, D., Coissac, E., et al. 2014. DNA metabarcoding multiplexing and validation of data accuracy for diet assessment: application to omnivorous diet. Mol. Ecol. Resour. 14(2): 306-323. doi:10.1111/17550998.12188.

Deagle, B.E., Jarman, S.N., Coissac, E., Pompanon, F., and Taberlet, P. 2014. DNA metabarcoding and the cytochrome c oxidase subunit I marker: not a perfect match. Biol. Lett. 10(9): 20140562. doi:10.1098/rsbl.2014.0562. 
Djurhuus, A., Pitz, K., Sawaya, N.A., Rojas-Márquez, J., Michaud, B., Montes, E., et al. 2018. Evaluation of marine zooplankton community structure through environmental DNA metabarcoding. Limnol. Oceanogr. Methods 16(4): 209-221. doi:10.1002/lom3.10237.

Eichmiller, J.J., Miller, L.M., and Sorensen, P.W. 2016. Optimizing techniques to capture and extract environmental DNA for detection and quantification of fish. Mol. Ecol. Resour. 16(1): 56-68. doi:10.1111/1755-0998.12421.

Eva, B., Harmony, P., Thomas, G., Francois, G., Alice, V., Claude, M., et al. 2016. Trails of river monsters: Detecting critically endangered Mekong giant catfish Pangasianodon gigas using environmental DNA. Glob. Ecol. Conserv. 7: 148-156. doi:10.1016/j.gecco.2016.06.007.

Furlan, E.M., and Gleeson, D. 2017. Improving reliability in environmental DNA detection surveys through enhanced quality control. Mar. Freshw. Res. 68(2): 388-395. doi:10.1071/MF15349.

Gansauge, M.-T., and Meyer, M. 2013. Single-stranded DNA library preparation for the sequencing of ancient or damaged DNA. Nat. Protoc. 8(4): 737. doi:10.1038/nprot.2013.038.

Goldberg, C.S., Strickler, K.M., and Fremier, A.K. 2018. Degradation and dispersion limit environmental DNA detection of rare amphibians in wetlands: Increasing efficacy of sampling designs. Sci. Total Environ. 633: 695-703. doi:10.1016/j.scitotenv.2018.02.295.

Green, H.C., and Field, K.G. 2012. Sensitive detection of sample interference in environmental qPCR. Water Res. 46(10): 3251-3260. doi:10.1016/j.watres.2012.03.041. 
440 Hinlo, R., Gleeson, D., Lintermans, M., and Furlan, E. 2017. Methods to maximise recovery of 441 442 environmental DNA from water samples. PloS One 12(6): e0179251. doi:10.1371/journal.pone.0179251.

443

444

445

446

447 448 449 450 451 452 453 454 455 456 457 458 459
Huson, D.H., Beier, S., Flade, I., Górska, A., El-Hadidi, M., Mitra, S., et al. 2016. MEGAN community edition-interactive exploration and analysis of large-scale microbiome sequencing data. PLoS Comput. Biol. 12(6): e1004957. doi:10.1371/journal.pcbi.1004957.

Jerde, C.L., Mahon, A.R., Chadderton, W.L., and Lodge, D.M. 2011. “Sight-unseen” detection of rare aquatic species using environmental DNA. Conserv. Lett. 4(2): 150-157. doi:10.1111/j.1755-263X.2010.00158.x.

Jerde, C.L., Olds, B.P., Shogren, A.J., Andruszkiewicz, E.A., Mahon, A.R., Bolster, D., et al. 2016. Influence of stream bottom substrate on retention and transport of vertebrate environmental DNA. Environ. Sci. Technol. 50(16): 8770-8779. doi:10.1021/acs.est.6b01761.

Kelly, R.P., Port, J.A., Yamahara, K.M., and Crowder, L.B. 2014. Using environmental DNA to census marine fishes in a large mesocosm. PloS One 9(1): e86175. doi:10.1371/journal.pone.0086175.

Kircher, M., Sawyer, S., and Meyer, M. 2011. Double indexing overcomes inaccuracies in multiplex sequencing on the Illumina platform. Nucleic Acids Res. 40(1): e3. doi:10.1093/nar/gkr771. 
460

461

462

463

464

465

466

467

468

469

470

471

472

473

474

475

476

477 478

479

Kocher, A., de Thoisy, B., Catzeflis, F., Valière, S., Bañuls, A.L., and Murienne, J. 2017a. iDNA screening: Disease vectors as vertebrate samplers. Mol. Ecol. 26(22): 6478-6486. doi:10.1111/mec.14362.

Kocher, A., Thoisy, B., Catzeflis, F., Huguin, M., Valière, S., Zinger, L., et al. 2017b. Evaluation of short mitochondrial metabarcodes for the identification of Amazonian mammals. Methods Ecol. Evol. 8(10): 1276-1283. doi:10.1111/2041-210X.12729.

Kondo, N.I., Nakagawa, M., Matsuzaki, S.-i., Ueno, R., Takamura, K., and Ito, H. 2016. DNA barcoding, environmental DNA and an ongoing attempt of detecting biodiversity in Lake Kasumigaura. J. Integr. Field Sci. 13: 21-29.

Liang, Z., and Keeley, A. 2013. Filtration recovery of extracellular DNA from environmental water samples. Environ. Sci. Technol. 47(16): 9324-9331. doi:10.1021/es401342b.

Lopes, C.M., Sasso, T., Valentini, A., Dejean, T., Martins, M., Zamudio, K.R., et al. 2017. eDNA metabarcoding: a promising method for anuran surveys in highly diverse tropical forests. Mol. Ecol. Resour. 17(5): 904-914. doi:10.1111/1755-0998.12643.

Majaneva, M., Diserud, O.H., Eagle, S.H., Boström, E., Hajibabaei, M., and Ekrem, T. 2018. Environmental DNA filtration techniques affect recovered biodiversity. Sci. Rep. 8(1): 4682. doi:10.1038/s41598-018-23052-8.

Maudet, C., Luikart, G., Dubray, D., Von Hardenberg, A., and Taberlet, P. 2004. Low genotyping error rates in wild ungulate faeces sampled in winter. Mol. Ecol. Resour. 4(4): 772-775. doi:10.1111/j.1471-8286.2004.00787.x. 
480 481 482 483 484 485 486 487 488 489 490 491 492 493 494 495 496 497 498

Pääbo, S., Poinar, H., Serre, D., Jaenicke-Després, V., Hebler, J., Rohland, N., et al. 2004. Genetic analyses from ancient DNA. Annu. Rev. Genet. 38(1): 645-679. doi:10.1146/annurev.genet.37.110801.143214.

Pérez, L.M., Fittipaldi, M., Adrados, B., Morató, J., and Codony, F. 2013. Error estimation in environmental DNA targets quantification due to PCR efficiencies differences between real samples and standards. Folia Microbiol. 58(6): 657-662. doi:10.1007/s12223-0130255-5.

Pilliod, D.S., Goldberg, C.S., Arkle, R.S., and Waits, L.P. 2014. Factors influencing detection of eDNA from a stream-dwelling amphibian. Mol. Ecol. Resour. 14(1): 109-116. doi:10.1111/1755-0998.12159.

Pimm, S.L., Jenkins, C.N., Abell, R., Brooks, T.M., Gittleman, J.L., Joppa, L.N., et al. 2014. The biodiversity of species and their rates of extinction, distribution, and protection. Science 344(6187): 1246752. doi:10.1126/Science.1246752.

Pochon, X., Bott, N.J., Smith, K.F., and Wood, S.A. 2013. Evaluating detection limits of nextgeneration sequencing for the surveillance and monitoring of international marine pests. PloS One 8(9): e73935. doi:10.1371/journal.pone.0073935.

Port, J.A., O'Donnell, J.L., Romero-Maraccini, O.C., Leary, P.R., Litvin, S.Y., Nickols, K.J., et al. 2016. Assessing vertebrate biodiversity in a kelp forest ecosystem using environmental DNA. Mol. Ecol. 25(2): 527-541. doi:10.1111/mec.13481. 
Rees, H.C., Maddison, B.C., Middleditch, D.J., Patmore, J.R.M., and Gough, K.C. 2014. The detection of aquatic animal species using environmental DNA - a review of eDNA as a survey tool in ecology. J. Appl. Ecol. 51(5): 1450-1459. doi:10.1111/1365-2664.12306.

Riaz, T., Shehzad, W., Viari, A., Pompanon, F., Taberlet, P., and Coissac, E. 2011. ecoPrimers: inference of new DNA barcode markers from whole genome sequence analysis. Nucleic Acids Res. 39(21): e145-e145. doi:10.1093/nar/gkr732.

Robson, H.L., Noble, T.H., Saunders, R.J., Robson, S.K., Burrows, D.W., and Jerry, D.R. 2016. Fine-tuning for the tropics: application of eDNA technology for invasive fish detection in tropical freshwater ecosystems. Mol. Ecol. Resour. 16(4): 922-932. doi:10.1111/17550998.12505 .

Rodgers, T.W., Xu, C.C., Giacalone, J., Kapheim, K.M., Saltonstall, K., Vargas, M., et al. 2017. Carrion fly-derived DNA metabarcoding is an effective tool for mammal surveys: evidence from a known tropical mammal community. Mol. Ecol. Resour. 17(6): e133e145. doi:10.1111/1755-0998.12701.

Shehzad, W., McCarthy, T.M., Pompanon, F., Purevjav, L., Coissac, E., Riaz, T., et al. $2012 a$. Prey preference of snow leopard (Panthera uncia) in South Gobi, Mongolia. PloS One 7(2): e32104. doi:10.1371/journal.pone.0032104.

Shehzad, W., Nawaz, M.A., Pompanon, F., Coissac, E., Riaz, T., Shah, S.A., et al. 2015. Forest without prey: livestock sustain a leopard Panthera pardus population in Pakistan. Oryx 49(2): 248-253. doi:10.1017/S0030605313001026. 
519 Shehzad, W., Riaz, T., Nawaz, M.A., Miquel, C., Poillot, C., Shah, S.A., et al. 2012b. Carnivore

520 diet analysis based on next-generation sequencing: application to the leopard cat

521

522 (Prionailurus bengalensis) in Pakistan. Mol. Ecol. 21(8): 1951-1965. doi:10.1111/j.1365294X.2011.05424.x.

523

524

525

526

527

528

529

530

531

532

533

534 535

536

537

538

539

Shogren, A.J., Tank, J.L., Andruszkiewicz, E.A., Olds, B., Jerde, C., and Bolster, D. 2016. Modelling the transport of environmental DNA through a porous substrate using continuous flow-through column experiments. J. Royal Soc. Interface 13(119). doi:10.1098/rsif.2016.0290.

Spens, J., Evans, A.R., Halfmaerten, D., Knudsen, S.W., Sengupta, M.E., Mak, S.S., et al. 2017. Comparison of capture and storage methods for aqueous macrobial eDNA using an optimized extraction protocol: advantage of enclosed filter. Methods Ecol. Evol. 8(5): 635-645. doi:10.1111/2041-210X.12683.

Strickler, K.M., Fremier, A.K., and Goldberg, C.S. 2015. Quantifying effects of UV-B, temperature, and $\mathrm{pH}$ on eDNA degradation in aquatic microcosms. Biol. Conserv. 183: 85-92. doi:10.1016/j.biocon.2014.11.038.

Takahara, T., Minamoto, T., Yamanaka, H., Doi, H., and Kawabata, Z.i. 2012. Estimation of fish biomass using environmental DNA. PloS one 7(4): e35868. doi:10.1371/journal.pone.0035868.

Thomsen, P.F., Kielgast, J.O.S., Iversen, L.L., Wiuf, C., Rasmussen, M., Gilbert, M.T.P., et al. 2012. Monitoring endangered freshwater biodiversity using environmental DNA. Mol. Ecol. 21(11): 2565-2573. doi:10.1111/j.1365-294X.2011.05418.x. 
540 Trape, S. 2009. Impact of climate change on the relict tropical fish fauna of Central Sahara:

541

542

543

544

545

546

547

548

549

550

551

552

553

554

555

556

557

558

559 threat for the survival of Adrar mountains fishes, Mauritania. Plos one 4(2): e4400. doi:10.1371/journal.pone.0004400.

Turner, C.R., Barnes, M.A., Xu, C.C., Jones, S.E., Jerde, C.L., and Lodge, D.M. 2014. Particle size distribution and optimal capture of aqueous macrobial eDNA. Methods Ecol. Evol. 5(7): 676-684. doi:10.1111/2041-210X.12206.

Vale, C.G., Pimm, S.L., and Brito, J.C. 2015. Overlooked mountain rock pools in deserts are critical local hotspots of biodiversity. PloS One 10(2): e0118367. doi:10.1371/journal.pone.0118367.

Valentini, A., Taberlet, P., Miaud, C., Civade, R., Herder, J., Thomsen, P.F., et al. 2016. Next-generation monitoring of aquatic biodiversity using environmental DNA metabarcoding. Mol. Ecol. 25(4): 929-942. doi:10.1111/mec.13428.

Vences, M., Lyra, M.L., Perl, R.G.B., Bletz, M.C., Stanković, D., Lopes, C.M., et al. 2016. Freshwater vertebrate metabarcoding on Illumina platforms using double-indexed primers of the mitochondrial 16S rRNA gene. Conserv. Genet. Resour. 8(3): 323-327. doi:10.1007/s12686-016-0550-y.

Verheye, H.M., and Dumont, H.J. 1984. The calanoid copepods of the Nile system. Hydrobiologia 110(1): 191-212. doi:10.1007/Bf00025791.

Walker, D.M., Leys, J.E., Dunham, K.E., Oliver, J.C., Schiller, E.E., Stephenson, K.S., et al. 2017. Methodological considerations for detection of terrestrial small-body salamander 

eDNA and implications for biodiversity conservation. Mol. Ecol. Resour. 17(6): 1223-

561 1230. doi:10.1111/1755-0998.12667.

562 Williams, K.E., Huyvaert, K.P., and Piaggio, A.J. 2017. Clearing muddied waters: Capture of 563 environmental DNA from turbid waters. PloS One 12(7): e0179282.

564 doi:10.1371/journal.pone.0179282.

565 Xiong, M., Shao, X., Long, Y., Bu, H., Zhang, D., Wang, D., et al. 2016. Molecular analysis of 566 vertebrates and plants in scats of leopard cats (Prionailurus bengalensis) in southwest China. J. Mammal. 97(4): 1054-1064. doi:10.1093/jmammal/gyw061.

568 Zhang, Z., Schwartz, S., Wagner, L., and Miller, W. 2000. A greedy algorithm for aligning DNA 569 sequences. J. Comput. Biol. 7(1-2): 203—214. doi:10.1089/10665270050081478. 
572 Table 1. Taxa expected and/or detected, either visually or via metabarcoding (read count

573 indicated). Also shown are the number of base mismatches for each species for the primer

574 pair used in this study.

\begin{tabular}{|c|c|c|c|c|c|c|c|c|c|c|c|c|c|}
\hline & & \multicolumn{3}{|c|}{ Actinopterygii } & \multicolumn{2}{|c|}{ Amphibia } & \multicolumn{3}{|c|}{ Reptilia } & \multicolumn{2}{|c|}{ Aves } & \multicolumn{2}{|c|}{ Mammalia } \\
\hline & Site & 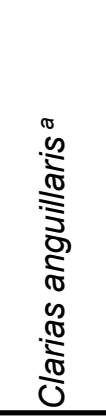 & 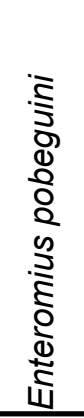 & 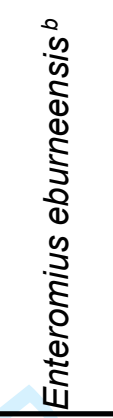 & 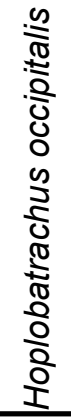 & 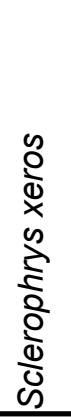 & 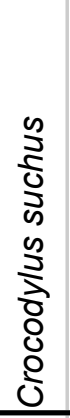 & 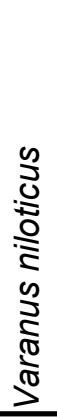 & $\begin{array}{l}\pi \\
0 \\
0 \\
\frac{1}{0} \\
0 \\
0 \\
0 \\
\frac{1}{4} \\
\frac{1}{1}\end{array}$ & 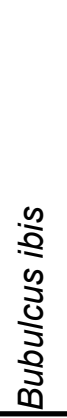 & 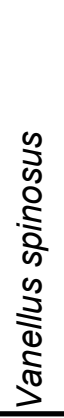 & $\begin{array}{l}0 \\
\frac{5}{2} \\
\frac{2}{2} \\
.00 \\
\frac{0}{\pi} \\
0\end{array}$ & 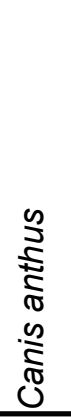 \\
\hline \multirow{3}{*}{ Expected } & Matmâta & $\checkmark$ & & & $\checkmark$ & $\checkmark$ & $\checkmark$ & $\checkmark$ & $\checkmark$ & $\checkmark$ & $\checkmark$ & & $\checkmark$ \\
\hline & Atar & $\checkmark$ & & & $\checkmark$ & $\checkmark$ & & & & & & & $\checkmark$ \\
\hline & Hamdoûn & $\checkmark$ & $\checkmark$ & $\mathrm{a}$ & $\checkmark$ & $\checkmark$ & & & & & & & $\checkmark$ \\
\hline \multirow{3}{*}{$\begin{array}{c}\text { Visual } \\
\text { observation }\end{array}$} & Matmâta & $\checkmark$ & & 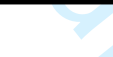 & $\checkmark$ & & $\checkmark$ & $\checkmark$ & & & & & \\
\hline & Atar & $\checkmark$ & & & $\checkmark$ & & & & & & & & \\
\hline & Hamdoûn & $\checkmark$ & & & $\checkmark$ & & & & & & & & \\
\hline \multirow{3}{*}{ eDNA detection } & Matmâta & 3691 & & & & & & & & & & 777 & \\
\hline & Atar & 148 & & & & & & & & & & & \\
\hline & Hamdoûn & 1549 & 683 & 2676 & & & & & & & & & \\
\hline \multirow{2}{*}{$\begin{array}{l}\text { Forward primer } \\
\text { mismatch } \\
\text { Reverse primer } \\
\text { mismatch }\end{array}$} & & $0^{*}$ & 0 & $0^{*}$ & 0 & 0 & $2^{*}$ & 2 & 0 & 0 & $0^{*}$ & 0 & 0 \\
\hline & & $0^{*}$ & 0 & $0^{*}$ & 0 & 1 & $2^{*}$ & 1 & 0 & 0 & $0^{*}$ & 0 & 0 \\
\hline
\end{tabular}

$575{ }^{a}$ Reads assigned to Clarias, likely C. anguillaris

$576{ }^{b}$ Reads assigned to E. eburneensis, likely either E. pobeguini or E. macrops

$577{ }^{c}$ Reads assigned to $C$. lupus, likely either C. anthus or C. lupus familiaris

$578 *$ Primer binding site sequence unavailable for this species. Indicated are the number of 579 mismatches to other species within the same genus.

580 


\section{FIGURE CAPTIONS}

583 Figure 1. Locations and photographic representations of sampling sites: Atar dam (photo

584 by G. Velo-Antón), Hamdoûn rock pool (photo by G. Velo-Antón ), and Matmâta river bed 585 (photo by JC Brito). Base map: Map data @2018 GeoBasis-DE/BKG (C2009), Google, Inst. 586 Geogr. Nacional, ORION-ME. Altitude adapted from USGS (2006).

588 Figure 2. Number of reads obtained following recovery of spiked DNA, which for positive 589 controls (PC1 and PC2) was rehydrated in $1 \mathbf{~ m l ~} \mathbf{d H}_{2} \mathrm{O}$ before filtering and for field samples 590 was rehydrated in $1 \mathrm{ml} \mathrm{dH}_{2} \mathrm{O}$ before adding to $5 \mathrm{~L}$ water samples. 




Figure 1. Locations and photographic representations of sampling sites: Atar dam (photo by G. Velo-Antón), Hamdoûn rock pool (photo by G. Velo-Antón ), and Matmâta river bed (photo by JC Brito). Base map: Map data (c)2018 GeoBasis-DE/BKG (@2009), Google, Inst. Geogr. Nacional, ORION-ME. Altitude adapted from USGS (2006).

$214 \times 217 \mathrm{~mm}(300 \times 300 \mathrm{DPI})$ 


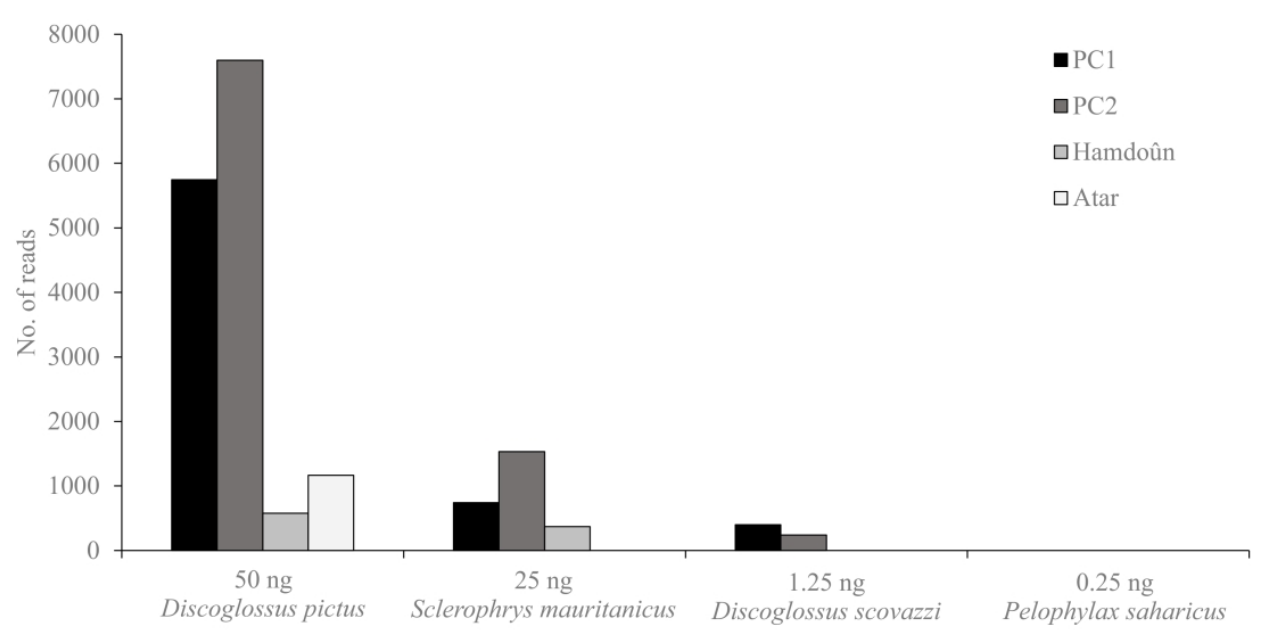

Desiccated mass of DNA for each species in the DNA spikes

Figure 2. Number of reads obtained following recovery of spiked DNA, which for positive controls (PC1 and $\mathrm{PC} 2$ ) was rehydrated in $1 \mathrm{ml} \mathrm{dH} 2 \mathrm{O}$ before filtering and for field samples was rehydrated in $1 \mathrm{ml} \mathrm{dH} 2 \mathrm{O}$ before adding to $5 \mathrm{~L}$ water samples.

$273 \times 143 \mathrm{~mm}(300 \times 300 \mathrm{DPI})$ 